\title{
Komisi Ombudsman Daerah dan Good Governance
}

\author{
Suparman Marzuki
}

\begin{abstract}
The establishing local ombudsman means establishing an institution which maybe an instrumen for inforcing society to control the state, not marely for the sake of the society itsself, but for the sake of the survivel of esspecially local govemment and generally for state. If Indonesian govemment can create a good fondation for local autonomy, they will attain goodprospect in the future coming.
\end{abstract}

\section{Pendahuluan}

Usaha membangun pemerintahan yang demokratis, bersih, berwibawa, taat hukum, serta menjunjung tinggi hak asasi manusia, secara normatif telah diberi landasan oleh Tap MPR Nomor XI/MPR/1998 tentang penyelenggaraan Negara yang bersih dan bebas dari Korupsi, Kolusi dan Nepotisme (KKN), TAP MPR Nomor VIII/MPR/2001 tentang Rekomendasi Arah Kebijakan Negara yang bersih dan Bebas dari KKN, UU Nomor 20 tahun 2001 tentang pemberantasan Tindak Pidana Korupsi, serta secara inplisit digariskan di dalam amandemen I, II dan III UUD 1945. Kerangka-kerangka hukum di atas cukup maju bila diukur dengan kompleksitas masalah yang dihadapi, tetapi sebagaimana pengalaman negara-negara yang baru lepas dari penjara kekuasaan otoritarian dan korup, dampak riil dari hukum belum terlihat. Nuansa KKN dan mis-manajemen di semua lini birokrasi, baik di birokrasi pelayanan publik, birokrasi pertahanan dan keamanan maupun birokrasi penegakan hukum belum menunjukkan perubahan yang cukup siqnifikan.
Dengan demikian tantangan bagi bangsa Indonesia bukan saja bagaimana membuat segala aturan berfungsi dengan pasti dan adil di tangan aparat penegak hukum yang pasti dan adil juga, tetapi juga bagaimana membangun sistem politik yang kondusif bagi tumbuhkembangnya pikiran-pikiran dan kebijakan-kebijakan baru di pelbagai bidang kehidupan sosial yang luas. Salah satu ide atau kebijakan baru yang memerlukan sikap responsif pemerintah dan rakyat adalah pembentukan Komisi Ombudsman di tingkat lokal (daerah) sebagai alternatif mendorong dan mengkondisikan terbangunnya pemerintah yang baik dan bersih.

Konsekuensi hukum dan politik diberlakukannya Undang-undang No 22 Tahun 1999 tentang Pemerintah Daerah dan Undang-undangan No 25 tentang Perimbangan Keuangan Pusat dan Daerah, maka sebagian besar urusan umum yang selama 50 tahun dipegang oleh pemerintah pusat akan menjadi urusan dan tanggungjawab daerah. Di dalam Pasal 1 sub h UU No. 22 Tahun 1999 
ditegaskan, "otonomi daerah adalah kewenangan daerah otonom untuk mengatur dan mengurus kepentingan masyarakat setempat menurut prakarsa sendiri berdasarkan aspirasi masyarakat sesuai dengan peraturan perundang-undangan", berarti peran pemerintah daerah cukup "tinggi" untuk mengambil inisiatif "menangkap" aspirasi masyarakat serta memfasilitasi keinginan masyarakat tersebut.

Kemudian kalau dibaca Pasal 7 sub I, antara lain disebutkan, "kewenangan daerah mencakup kewenangan dalam seluruh bidang pemerintahan, kecuali kewenangan dalam bidang politik luar negeri, pertahanan, peradilan, moneter, dan fiskal, agama serta kewenangan bidang lain"... kewenangan bidang lain sebagaimana termuat dalam sub 2 , antara lain disebutkan adalah “...pembinaan dan pemberdayaan sumber daya manusia...". Selanjutnya masih ada kewenangan daerah yang lainnya, sebagaimana termuat dalam Pasal 10, sub $2 \mathrm{~d}$, berupa "penegakan hukum terhadap peraturan yang dikeluarkan oleh daerah atau yang dilimpahkan kewenangannya oleh pemerintah.."

Dengan adanya otonomi daerah, maka akan membuka kesempatan bagi masyarakat untuk berpartisipasi dalam berbagai aktivitas politik di tingkat lokal. Di samping itu, pelaksanaan otonomi daerah akan meningkatkan kemampuan pemerintah daerah dalam memperhatikan hak-hak masyarakat sehingga akan tercipta proximity antara aparat pengambil keputusan di tingkat lokal dengan para konstituennya, sehingga pembagian kekuasaan akan semakin dipertimbangkan sebagai jaminan bahwa tuntutan masyarakat itu didengar, di samping pelayanan umum akan menjadi semakin simetris dengan preferensi warganya. Dengan otonomi daerah, maka asimetri informasi antara masyarakat dengan para pengambil keputusan yang dimasa lalu terjadi sebagai akibat dikelolanya sebagian besar urusan umum oleh pemerintah pusat akan semakin diperkecil. Pemerintah Daerah yang diasumsikan lebih mengetahui preferensi umum warganya dibandingkan pemerintah pusat, akan semakin mendekatkan pada tujuan otonomi daerah tadi.

Kegagalan yang mungkin terjadi dari pencapaian tujuan otonomi daerah ini adalah kemampuan elit lokal, prosedur demokrasi, serta proses politik antara warga dengan otoritas kebijakan itu sendiri dalam menentukan pilihan publik (public choice). Kebijakan desentralisai dan otonomi daerah harus menciptakan ruang bagi partisipasi warga dan masyarakat dalam menilai kinerja pemerintah daerah. Agar masyarakat dapat berperan dengan baik, maka Pemerintah Daerah harus terbuka (transparan) dalam berbagai hal, sehingga pertanggungjawaban pemerintah daerah kepada masyarakat (publik) menjadi obyektif dan wajar. Berkenaan dengan perubahan paradigma tersebut dan di dukung dengan tuntutan masyarakat yang semakin kuat, merupakan tantangan bagi pemerintah daerah untuk memberikan pelayanan administrasi pemerintahan dan pelayanan umum yang lebih efektif dan efesien, paripurna dan transparan. Untuk itu diperlukan inovasi baru dalam penyelenggaraan pemerintahan yang meliputi reorientasi kelembagaan, sikap aparatur, dan yang terpenting adalah adanya kemauan politik (political will) dari birokrasinya itu sendiri.

Selama ini ada kesan antipati dari masyarakat terhadap birokrasi di daerah 
sebagai akibat kurang baiknya kualitas pelayanan dan administrasi pemerintahan yang diberikan. Nuansa praktek Kolusi, Korupsi dan Nepotisme (KKN) dan mal-administrasi di semua lini birokrasi ditambah dengan kurang transparan dan minimnya publikasi peraturan-peraturan umum menjadi suatu perilaku yang membudaya dan sangat sulit untuk ditembus. Kenyataan lainnya adalah tidak adanya wadah bagi masyarakat sebagai konsumen atau pengguna layanan umum untuk dapat mengawasi dan menyampaikan keluhan-keluhan atas ketidaknyamanan/ penyelewengan dari aparat atau institusi administratif lainnya. Dalam konteks itulah keberadaan dan beroperasinya sebuah lembaga yang bemama Komisi Ombudsman' daerah menemukan urgensi dan signifikansinya.

\section{Komisi Ombudsman dan Good Governance}

Penyelenggaraan pemerintahan daerah yang baik (local good governance) adalah prasyarat mutlak bagi terselenggaranya . pembangunan berkelanjutan yang bertumpu pada masyarakat. Hanya pemerintahan yang baik yang dapat mengalokasikan sumber daya dan masalah publik secara efisien, merespon kebutuhan kritis masyarakat, menjalankan demokrasi secara efektif melalui partisipasi publik, akuntabilitas, dan transparansi. Pemerintahan yang baik juga dapat memperbaiki kegagalan pasar (market failure) dan menyediakan barang publik yang tidak disuplai oleh pasar. Pemerintah mungkin juga dapat meredistribusi pendapatan melalui pajak, memberikan kesempatan yang sama untuk pendidikan, kesehatan dan pekerjaan, mengurangi resiko dengan penyediakan pensiun dan asuransi pekerja. Lebih jauh pemerintah yang baik dapat menanamkan nilai moral, agama dan budaya.

Lebih-lebih isu Good Govarnance telah menjadi salah satu isu penting di dunia dewasa ini seiring dengan menguatnya tuntutan demokratisasi, supremasi hukum dan hak asasi manusia di dunia. Sebuah lembaga yang banyak meneliti dan mempublikasi masalah-masalah yang berkaitan dengan hal ini, yaitu Transparansi internasional ${ }^{2}$ menyebutkan adanya 21 indikator untuk menilai suatu pemerintahan dikatakan baik atau tidak, yaitu:, (1) legislature, (2) executive, (3) judiciary, (4) ombudsman, (5) anti-corruption Agencies, (6) public service, (7) local

"Kata "Ombudsman" sebenarnya berasal dari Swedia yang berarti "perwakilan". Banyak nama lain digunakan untuk menggantikan kata Ombudsman. Sebagai contoh, Defender del Pueblo adalah intitusi Ombudsman yang digunakan di sejumlah negara berbahasa Spanyol (seperti Spanyol, Argentina, Peru dan Colombia). Parliamentary Commissioner for Administration di Srilanka dan Ingris; Mediateur de la Republique di Perancis, Gabon, Mauritania, Senegal; Public Protectordi Afrika Selatan; Protectour du Citoyen di Quebec; Volksanwaltschaft di Austria, Public Compalint Commisison di Nigeria; Provedor de Justica di Portugal; Fifenso Vivico di ltalia; Investigator-General di Gambia; Citizens Aide di lowa; Wafaqi Mohtasib di Pakistan dan Lok Ayukta di India adalah sejumlah nama-nama Ombudsman di seluruh dunia.

2Jeremy Pope, (ed), Transparency Intemational Source Book 2000, Confronting Corruptions: The Elements of a National Integrity System (Berlin: Transparency International, 2000). Buku ini juga dapat diakses melalui situs http:/www.transprancy.org/sourcebook/index.html 
govermment, (8) media, (9) civil society, (10) private sector, (11) intemational agencies, (12) elections, (13) administrative law, (14) public servie ethnics, (15) conflict of interests, (16) public procurement, (17) good financial management, (18) access to information, (19) citizens voice, (20) competition policy, and (21) fighting corruption.

Di samping itu, suatu pemerintahan akan dikatakan baik dan bersih apabila memenuhi asas umum pemerintahan yang baik (Algemene beginselen van behoorlik bestuur) yaitu ${ }^{3}$ : (1) asas kecermatan formal, yatu cermat. dalam mempersiapkan serta mengeluarkan keputusan institusi yang bersangkutan, serta jujur dalam mempertimbangkan semua fakta yang relevan dan kepentingan para pihak; (2) asas fairplay, yaitu dalam mengeluarkan keputusan tidak bersikap menghalang-halangi kesempatan orang yang berkepentingan untuk memperoleh keputusan yang menguntungkan baginya; (3) asas pertimbangan, bahwa keputusan pejabat publik harus disertai dengan pertimbangan yang memadai. Pertimbangan didukung oleh fakta-fakta yang benar dan relevan. Pertimbangan kepastian hukum putusan tidak boleh bertentangan dengan kebiasaan yang telah dipublikasikan, dan tidak bersifat umum namun kongkrit; (4) asas kepastian hukum formal, artinya mengandung kejelasan dan tidak samarsamar; (5) asas kepastian hukum material, artinya keputusan dari pejabat publik yang bersifat membebani tidak boleh diberlakukan secara surut; (6) asas kepercayaan, yaitu bahwa suatu keputusan telah menimbulkan harapan-harapan dengan janji/rencana maka janji semacam itu tidak boleh diingkari. Kepercayaan dapat ditimbulkán dengan pemberlakuan kebijakan yang sama dengan pemberlakuan kebijakan yang sama dalam kurun waktu tertentu yang cukup lama; (7) asas persamaan, hal atau keadaan yang sama diperlakukan secara sama pula. Keadaan tersebut harus sama relevansinya; relevan dari segi kepentingan yang akan diperhatikan dengan pengeluaran keputusan yang bersangkutan; (8) asas kecermatan material, artinya bahwa kerugian yang ditimbulkan tidak melebihi keuntungan/manfaat yang diperoleh dengan adanya keputusan pejabat publik yang bersangkutan, dan (9) asas keseimbangan, ada keseimbangan antara sanksi yang diterapkan dengan bobot pelanggaran yang dilakukan.

Tidak diragukan lagi bahwa sistem Ombudsman merupakan salah satu pilar demokrasi yang menghormati dan memajukan asas negara hukum sekaligus merupakan kebutuhan bagi kekuatan demokrasi sipil4 , terutama bagi negara-negara yang sedang dalam proses transisi menuju negara demokratis, sebagaimana yang dilakukan Afrika Selatan segera setelah negera tersebut lepas dari cengkraman kekuasaan politik perbendaan warna kulit. Sebagaimana banyak dilalaporkan dan dilansir media massa

${ }^{3}$ Indroharto, Usaha Memahami Undang-Undang Tentang Peradilan tata Usaha Negara (Jakarta: Pustaka Sinar Harapan, 1991).

"Lihat Cf. Emile Francis Short, The Development and Future of the Ombudsman Concept in Afrika", makalah untuk Konfrensi Intemational Ombudsman Institute ke-7, Durban Afrika Selatan 30 Oktober-2 November 2000. 
internasional, Afrika Selatan relatif sukses melalui tahap-tahap sulit, dan sekarang menjadi salah satu contoh negara yang berhasil membangun landasan bagi pemerintahan yang baik dan bersih.

Persoalan bagi Indonesia adalah bahwa praktek penyelenggaraan pemerintahan yang baik di Indonesia masih jauh dari harapan. Tingkat korupsi, kolusi, dan nepotisme (KKN) di Indonesia menurut hasil penelitian Transparansi Internasional selalu masuk dalam kategori tiga besar. Demikian juga dengan penyalahgunaan kewenangan dan pelanggaran terhadap hak-hak masyarakat masih di atas rata-rata umumnya negara berkembang. Bukan mustahil berbagai kekeliruan penyelenggaraan pemerintahan dalam sikala nasional ini juga tercermin dalam tingkat lokal.

Salah satu akar persoalan dari buruknya penyelenggaraan pemerintahan di Indonesia, termasuk pemerintahan daerah, adalah sangat dominannya birokrasi. Para analis politik dan pemerintahan menyebut Indonesia, meminjam terminologi G.O'Donnell dan Muchtar Mas'ud, sebagai negara birokratik (bureaucratic state) dan koorporatis (coorporate state) $)^{5}$. Dalam tatanan ini birokrasi sebagai instrumen pemerintahan merupakan kekuatan dominan yang tidak hanya relatif mandiri berhadapan dengan elit politik dan masyarakat sipil, tetapi menjadi kekuatan dominan yang mampu mengatasi keduanya. Para birokrat memainkan peran sebagai poros pemerintahan yang mengatur, mengintervensi, dan mengendalikan segala segi kehidupan masyarakat.

Birokrasi pemerintahan juga beroperasi sebagaimana organisasi perusahaan yang mengontrol setiap elemen sosial dan kelembagaan untuk memenuhi tujuan yang telah ditetapkan. Dengan demikian maka wajar bila dalam tatanan politik seperti ini kontrol dari sektor swasta, masyarakat sipil, dan organisasi independen menjadi lumpuh. Menghadapi civil society yang lemah dan tidak terorganisir, pemerintah bukannya melakukan penguatan (empowering) terhadap masyarakat melainkan memanfaatkan kesempatan ini untuk menyalahgunakan wewenang melalui penyusunan peraturan yang tidak transparan, birokrasi yang tidak efisien, mengadakan pungutan secara liar, melakukan korupsi, dan berkolusi dengan dunia usaha untuk memarkup biaya proyek. Sementara dunia usaha memanfaatkan kelemahan kontrol sosial dan pemerintahan untuk meraih keuntungan sebanyak-banyaknya dengan cara instant. Hal ini mendorong tumbuhnya iklim dunia usaha yang tidak sehat, kemajuan usaha tidak ditentukan oleh efisiensi perusahaan melainkan oleh seberapa dekat pengusaha dengan pejabat, penghindaran pajak, dan monopoli.

Untuk mewujudkan pemerintahan yang baik sebagai amanat reformasi maka dibutuhkan terobosan dari sektor swasta, masyarakat sipil, dan pemerintah. Penyelenggaraan pemerintahan yang baik perlu di dukung oleh tiga komponen utama yang harus saling mendukung yaitu: Hubungan yang baik antara berbagai komponen

'Lihat Guillermo O"Donnel, dkk, Transisi Menuju Demokrasi: Tinjauan Berbagai Perspektif (Jakarta: LP3ES, 1993), dan lihat juga, Mochtar Mas'oed, Ekonomi dan Struktur Politik Orde Baru 1966-1971 (Jakarta: $\mathrm{Tp}, 1989)$. 
masyarakat dengan birokrasi, Sistem hukum yang adil dan dapat melindungi masyarakat, dan Penyelenggaraan administrasi pemerintahan yang transparan dan akuntabel.

Dari segi kelembagaan usaha untuk mendorong penyelenggaraan pemerintahan yang baik perlu didukung oleh tumbuhnya berbagai institusi yang dapat menerima dan menindaklanjuti keluhan masyarakat ${ }^{6}$ serta memediasi hak dan kepentingan masyarakat terhadap pemerintah. Salah satu institusi yang dapat mendorong penyelenggaraan pemerintahan yang baik adalah Ombudsman. Kelahiran lembaga ini sangat strategis terutama dalam situasi masih lemahnya masyarakat sipil - sebagai konsumen dari pelayanan umum dan administrasi pemerintahan daerah — dalam mengartikulasi hak dan kepentingannya. Dengan demikian lembaga ini dapat menjadi media bagi masyarakat sipil untuk menyampaikan keluhan dan kepentingannya kepada pemerintah. Lembaga ini juga dapat bertindak secara indipenden untuk melindungi hak-hak warga dari perbuatan mal-administrasi ${ }^{7}$ yang dilakukan oleh aparat pemerintah daerah.
Meskipun Komisi Ombudsman merupakan komisi yang relatif baru dikenal luas pada dekade 1980-an, tetapi dengan cepat muncul sebagai komisi penting dan strategis di beberapa negara di kawasan Amerika, Eropa, Australia, Afrika Selatan dan Asia. Tidak kurang 107 negara telah memiliki komisi Ombudsman. Bahkan untuk benua Afrika saja hingga tahun 2000 telah mencapai 26 buah komisi yang ada di beberapa negara di kawasan tersebut. Perkembangan terbaru menunjukkan bahwa kecenderungan mendirikan komisi Ombudsman lokal atau daerah semakin menguat, sebagaimana telah dilakukan oleh: Inggris, Australia, Meksiko, Pakistan dan Belgia. Bahkan beberapa negara hanya punya Ombudsman daerah seperti Amerika, Swiss, Italia, Kanada dan India

Dengan perkembangan tersebut maka pembentukan Komisi Ombudsman daerah, di samping tetap mempertahankan Ombudsman Nasional merupakan tuntutan yang amat mendesak sejalan dengan tuntutan yang berkaitan dengan implementasi desentralisasi/otonomi daerah " yang sudah barang tentu membutuhkan kekuatan-

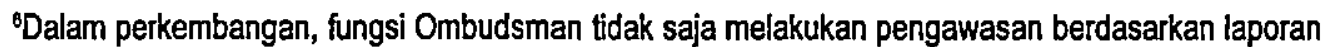
masyarakat, saat ini lembaga Ombudsman sering bertindak atas inisiatif sendiri, selain itu sasaran keluhan masyarakat (types of admisisible complaints) juga mengalamai perkembangan. Pengertian maladminsitrasi tidak sekadara bersifatformil dalam arti tidak sesuai dengan kewajiban sebagaimana ditulis dalam peraturan perundangan namun juga mencakup kapatutan (equity). Tidak adanya tansparansi serta tindakan menolak member informasi (lack of transparency and refusal of acces to information) oleh pejabat publik kini telah menjadi bagian dari maladministrasiitu sendiri.

'Defenisi maladministrasi menurut laporan tahunan 1997 Ombudsman Eropamenyatakan bahwa: "maladministration accurs when a public body fail to act in accordance with the rule or principle which is binding upon it", Lihat, The European Ombudsman ReportFor 1999 halaman 17.

${ }^{8}$ Rekomendasi Lokakarya I dan II yang berlangsung di Bali pada 9 April 2000 yang lalu menunjukkan bahwa pendirian Ombudsman daerah merupakan langkah yang tepat, relevan dan strategis serta sangat siqnifikan terhadap kebijakan politik desentralisasi. 
kekuatan kontrol bagi kekuasaan lokal dan penguatan masyarakat. Kehadiran Ombudsman daerah diharapkan akan mendapatkan dukungan kultural yang kuat, karena meskipun kelembagaan Ombudsman muncul dan berkembang di Barat, tetapi dalam sejarah sosial masyarakat, kita mengenal adanya praktek-praktek yang fungsinya menyerupai Ombudsman, yaitu praktek kepokrolan. "Institusi " kepokorolan tersebut dimanfaatkan oleh anggota masyarakat untuk menyelesaikan berbagai persoalan hukum yang mereka hadapi. Sejalan dengan. perkembangan jaman. Dalam konteks kekinian, berbagai kegiatan yang dilakukan oleh berbagai Lembaga Swadaya Masyarakat (LSM) seperti Yayasan Lembaga Bantuan Hukum Indonesia, Wahana Lingkungan Hidup (Walhi), Yayasan Lembaga Konsumen Indonesia (YLKI) dan lain-lain, sebenarnya dapat dikatakan telah menjalankan sebagian fungsifungsi Ombudsman. Praktek-praktek tersebut jelas menunjukkan bahwa upaya menghadirkan institusi ombudsman di daerah ada kontekstualitasnya.

Memang ada seagian kalangan yang mengkhawatiran kehadiran Komisi Ombudsman dapat tumpang tindih peran dengan LSM atau NGO, dan menyarankan untuk memberdayakan lembaga-lembaga yang sudah ada ${ }^{9}$ ? Kekhawatiran ini tidak perlu ada karena antara NGO dan Komisi Ombudsman memiliki perbedaan yang sangat jelas. Pertama, NGO didirikan penuh atas prakarsa masyarakat, relatif tidak memiliki anasir kekuasaan negara atau pemerintah di dalamnya, tegas berdiri di luar negara, dan mengambil jarak yang tegas dengan negara, dan Kedua, NGO secara tegas menjadi kekuatan eksternal yang memiliki kekuatan moril dan daya desak politik pada elite kekuasaan, tetapi sulit menjangkau lapis bawah birokrasi. Sementara Komisi Ombudsman, dimanapun di pelbagai negara, memperoleh legalisasi politik dan hukum dari negara; apakah itu dari eksekutif atau dari parlemen. Dengan posisi ini negara diikat secara politik dan Yuridis untuk mau tidak mau menjadi bagian dari kekuatan masyarakat dalam melakukan kontrol pada birokrasi negara dan mau tidak mau harus mendengar saran-saran perbaikan dari Komisi. Dengan kata lain, Komisi memiliki daya dukung dan daya desak politik, hukum dan moral dari masyarakat dan negara yang dapat menyentuh semua lini birokrasi dari atas sampai bawah; sesuatu yang relatif sulit untuk dilakukan oleh NGO. Dengan posisi semacam itu pula, antara NGO dan Komisi Ombudsman tidak mungkin akan menjadi rivalitas, apalagi konflik. Keduanya merupakan kekuatan bersama yang dapat melakukan koordinasi bagi upaya membangun pemerintahan yang bersih melalui dan dengan perannya masing-masing.

${ }^{8}$ Penolakan dan perdebatan tentang perlu tidaknya Ombudsman bukan hal bar. Di Belanda saja perdebatan tentang siqnifikansi pembentukan Ombudsman berlangsung 20 tahun sebelum akhirnya pada tahun 1981 deakomodasi di dalam konstitusi mereka, meskipun di sana sistem peradilan dan institusi demokrasi lainnya telah berjalan dengan baik. Hal yang sama juga terjadi di Perancis, pada mulanya mereka menetang pembentukan Ombudsman karena menganggap PTUN mereka paling efektif di dunia, meski kemudkan pada tahun 1973 Ombudsman didirikan. 
Pengalaman sejumlah negara, Philipin, Australia, Amerka, Denmark dan sejumlah negara Skandinavia, peran NGO dan Komisi Ombydsman dapat berjalan seirama karena dipersatukan oleh idealisme yang sama, yaitu mewujdukkan pemerintah yang baik.

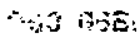

\section{Pérán dan Kewenangan Ombudsman} s.:

Komisi Ombudsman pada umumnya berperan menangani keluhan masyarakat, menyangkut keputusan atau tindakan administrasi pemerintahan dan pelayanan umum, melindungi orang dari pelanggaran hak, penyalahgunaan kekuasaan, kesalahan, pengabaian, keputusan yang tidak adil dan kesalahan administratif. Peranan Ombudsman seperti itu diarahkan agar kinerja admnisistrasi pemerintahan dapat diperbaiki dan ditingkatkan, tindakan-tindakan pemerintah dapat lebih terbuka dan, pemerintah dengan birokrasinya bisa lebih akuntabel terhadap masyarakat luas. Di samping itu Komisi Ombudsman mempunyai kewenangan untuk melakukan penyelidikan secara obyektif atas keluhan masyarakat umum mengenai pelayanan umum dan adminisatrasi pemerintahan, dan dapat juga atas inisiatif sendiri melakuan penyelidikan, sekalipun keluhan tersebut belum didaftarkan.

Selain peran dan kewenangan demikian itu, institusi Ombudsman juga berwenang menyelidiki apakah administrasi yang dilaksanakan pemerintah bertentangan dengan hukum atau mengandụng unsur-unsur ketidakadilan. Jika ternyața penyelidikan obyektif tersebut tidak mampu mengungkap kesalahan administratif, maka institusi Ombudsman dapat mengajukan rekomendasi kepada Pemerintah Daerah untuk memperbaiki atau menyempurnakan sikap atau tindakannya; dan melaporkan aktivitasnya dalam kasus-kasus yang spesifik kepada pemerintah atau kepada pengeluh (publik yang mengeluhkan masalahnya), dan jika rekomendasi spesifik tersebut: tidak diterima pemerintah maka rekomendasai tersebut dapat diajukan ke partemen institusi Ombudsman juga membuat laporan tahunan atas pekerjaannya kepada parlemen dan juga kepada publik secara umum.

Ombudsman tidak berwenang membuat keputusan yang mengikat secara hukum kepada pemerintah karena Ombudsman merupakan "Magistrature of Influence" (Mahkamah Pemberi Pengaruh) bukan "Magistrature of Sanctions ${ }^{0}$ (Mahkamah pemberi Sanksi), ia hanya membuat rekomendasi - atas dasar penyelidikannya - untuk mendorong perubahan ke arah yang lebih baik. Landasan yang sangat penting bagi Ombudsman adalah independensinya terhadap lembaga pemerintah (birokrasi). Supaya investigasi dan rekomendasi Ombudsman dapat dipercaya (kredibel) baik oleh pemerintah maupun masyarakat, maka Ombudsman .harus menjaga dan melindungi integritas dan imparsialitasnya. ${ }^{10}$

10 Umumnyainstitusi Ombudsman dalam sektor administrasi pemerintahan dan pelayanan umum mempunyai yurisdiksi yang luas atas lembaga-lembaga pemerintah. Di beberapa negara, yurisdiksi Ombudsman.juga memasuki wilayah lembaga-lembaga pengadilan, kepolisian dan militer. Sementara itu di tempat yang lain yuridiksi Ombudsman justru tidak memasuki wilayah-wilayah tersebut. Sejumlah negara telah membentuk Ombudsman yang secara khusus hanya menangani salah satu aspek dari pemerintahan seperti akses terhadap informasi, lembaga pemasyarakatan, kepolisian, militer atau etika pegawai negeri. 
Ombudsman bukanlah pelaksana kekuasaan karena wewenang yang dimilikinya hanyalah mencakup aspek-aspek pengawasan agar tidak terjadi penyimpangan atau penyelewengan. Mengawasi pada hakekatnya merupakan tindakan untuk secara terus menerus mengingatkan pelaksana agar tetap memperhatikan ataupun mempedomani aturan, kaidah, norma serta hukum yang berlaku. Oleh karena Ombudsman bukan pelaksana kekuasaan maka secara kelembagaan juga bukan menjadi bagian dari kekuasaan sehingga dalam status tersebut ia dapat menghindarkan diri dari situasi "conflict of Interest" ". Dengan kata lain ia lebih mandiri dan independent ${ }^{12}$

Ombudsman tidak memiliki kepentingan dengan status kekuasaan juga tidak berada dalam pemerintahan, oleh karena itu memiliki kebebasan bertindak dalam menentukan pengawasan serta hasil-hasil pengawasan. Satu-satunya kesamaan antara Ombudsman dengan otoritas pemerintahan adalah misi kepentingannya pada masyarakat dalam mewujudkan dan memberi kesejahteraan, ketertiban serta keadilan.. Misi tersebut diharapkan akan lebih mudah diwujudkan di dalam lingkup kewenangan yang tidak terlalu luas, sebagaimana kesulitan yang dialami oleh Komisi Ombudsman Nasional (KON). Kewenangan yang luas dan terpusat telah memperlemah fungsi kontrol karena kewenangan tersebut cenderung untuk selalu mempebesar area kekuasaannya, baik secara fungsional maupun institusional. Karena itu distribusi kewenangan/kekuasaan pemerintahan dari pusat ke daerah otonom padai intinya merupakan juga pelimpahan kekuasaan dan kewenangan, dan berarti pula peluang terjadinya penyalahgunaan akan juga didistribusikan ke daerah-daerah. Disinilah pentingnya institusi pengawasan independen dibentuk di daerah-daerah, selain akan lebih meningkatkan efisiensi dan efektifitas pengawasan karena faktor-faktor kedekatan wilayah, kondisi setempat, sosial budaya, dan sebagainya, juga dapat mendorong fungsi KON lebih optimal pada sektor-sektor strategis pusat yang menjadi kewenangan Pusat. Dan sebagai institusi independen, Ombdusman daerah tidak boleh berada dalam subordinasi Ombudsman Nasional (KON), atau bertanggungjawab kepada KON. Ombudsman daerah dan KON dapat melakukan kerjasama dan koordinasi antara lain dalam bidang peningkatan SDM, penelitian, pelatihan dan sebagainya.

\section{Simpulan}

Tantangan terbesar yang dihadapi Indonesia adalah bagaimana membangun

${ }^{11}$ Antonius Sujata, Peran Ombudsman Dalam Upay Membangun Good Hovernance, Makalah pada Forum Diskusi hukum Bandung dan fakultas Hukum Universitas Pasundan, diselenggarakan di Bandung pada tanggal 17 September 2001

${ }^{12}$ Tiga aspek independensi dan tiga sikap dasar yang harus dipegang teguh oleh institusi Ombudsman. Pertama, Independensi Institusional, artinya bukan bagian dati institusi negara yang telah ada. Kedua, independensi Personal, artinya person Ombudsman garuslah seorang yang terpercaya. independensi Fungsional, artinya tidak boleh dicampuri atau mendapat tekanan dari mana saja. Ketiga, prosedur kerja tidak kaku dan terlalu formal. Keempat, tidak diperlukan kuasa/bantuan hukum; pelapor/korban maladministrasi kangsung mendatangi Ombudsman, dan kelima, tidak dipungut biaya. 
pemerintahan yang memiliki kredebelitas sehingga dipercaya rakyat. Membangun kredebelitas dapat diproses serta dikembangkan melalui program-program yang memberi kesejahteraan dan pelayanan yang sebaik-baiknya kepada masyarakat serta secara konsisten dan konsekuen menegakkan hukum. Selama lebih dari tiga dekade peran kekuasaan pemerintah sangat dominan dimana masyarakat lebih banyak menjadi objek daripada objek. Masyarakat yang semestinya memiliki peran melakukan pengawasan justru lebih banyak diawasi. Oleh sebab itu pembentukan Ombudsman harus dilihat sebagai wujud pemberdayaan masyarakat dalam melakukan pengawasan guna mengupayakan secara berkesinambungan kemudahan pelayanan yang efektif dan berkualitas oleh institusi pemerintah kepada masyarakat; membantu menciptakan serta mengembangkan situasi dan kondisi yang kondusif demi terselenggaranya pemerintahan yang baik dan bersih, serta bebas KKN; memperioritaskan pelayanan yang lebih peka terhadap tuntutan dan kebutuhan masyarakat dengan memberi pelayanan optimal serta membina koordinasi dan kerjasama yang baik dengan semua pihak; menciptakan lingkungan dan suasana kerja dengan komitmen penuh, standar integritas dan akuntabilitas tinggi; melaksanakan manajemen terbuka, serta memberikan kesempatan yang terus menerus - kepada seluruh staff untuk meningkatkan pengetahuan serta profesionalisme dalam menangani keluahan masyarakat; dan mendorong peningkatan kesadaran hukum aparatur pemerintah, peradilan dan lembaga legislatif.

Pemerintah yang baik dan bersih serta masyarakat yang kuat merupakan asset negara yang sangat penting karena akan semakin memperkuat posisi dan daya tahan negara itu. Sudah cukup banyak bukti kehancuran suatu negara, atau setidaktidaknya lemahnya fondasi moral dan politik negara akibat lemahnya masyarakat dan korups-nya pemerintahan yang menyebabkan negara itu berkembang sangat lamban di pelbagai bidang; ekonomi, politik, dan hukum, sebagaimana yang sekarang sedang kita alami. Kekuasaan Orde Baru yang sangat kuat dan otoriter di atas lemahnya masyarakat sipil, dan meluasnya KKN hanya mampu bertahan 30 tahun, tetapi krisis sosial yang diakibatkannya sedemikian besar yang tidak terbayangkan kapan mampu diatasi.

Pembentukan Ombudsman daerah adalah pembentukan institusi yang dapat menjadi instrumen kekuatan masyarakat mengkontrol negara; tidak untuk kepentingan masyarakat semata-mata tetapi untuk kepentingan daya tahan pemerintahan daerah bersangkutan dan negara pada akhirnya. Desentralisasi oleh beberapa kalangan dinilai sebagai pertaruhan terakhir masa depan republik ini. Jika kita berhasil meletakkan pondasi otonomi yang kondusif bagi tumbuhkembangnya pemerintahan yang baik dan bersih, maka masa depan Indonesia sangat cerah; tetapi sebaliknya jika kita gagal, maka yang akan terjadi adalah perluasan masalah yang akan mengancam Indonesia, tidak saja sebagai negara kesatuan Rl, tetapi juga sebagai bangsa. $\square$

\section{Daftar Pustaka}

Franwcis, CF. Emile Francis. The Development and Future of the Ombudsman Concept in Afrika. Makalah untuk 
Konfrensi International Ombudsman Institute ke-7. Durban Afrika Selatan 30 Oktober-2 November 2000.

Indoharto. Usaha Memahami Undang-Undang Tentang Peradilan Tata Usaha Negara. Jakarta: Pustaka Sinar Harapan, 1991. Mas'oed, Mochtar. Ekonomi dan Struktur Politik Orde Baru 1966-1971. Jakarta: LP3ES, 1989.

O'Donnel, Guillermo, dkk. Transisi Menuju Demokrasi: Tinjauah Berbagai Perspektif. Jakarta: LP3ES, 1993.

Commonwealth Ombudsman's Office, Canberra, Second Editon. A Good Practice Guide for effective Complaint handling. 1999

Pope, Jeremy (ed). Transparency Intemational Source Book 2000, Confronting Corruptions: The Elements of a National Integrity System (Berlin: Transparency International, 2000).

Sujata, Antonius. Peran ombudsman Dalam. Upaya Membangun Good Governance. Makalah pada Forum Diskusi Hukum Bandung dan fakultas Hukum Universitas Pasundan. 17 September 2001

The Europan Ombudsman For 1999

www.usombudsman.org/References/ EssertiaCharaderisticsclassicalombudsman
www.usombudsman.org/References/ theombudsman

www.usombudsman.org/References/ municiplegovernmentombudsman

www. usombudsman.org/References/ modelshieldlaw

Www. usombudsman.org/References/ modelombudact

www.usombudsman.org/References/ publicsectorombudsman

www.usombudsman.org/ServicesActivities/ newsletter

www.usombudsman.org/Membership/membership

www.usombudsman.org/AboutUSOA/association

www.ombudsman.or.id/membangun

www.ombudsman.or.id/ttgkami-falsafah

www.ombudsman.or.id/ttgkami-misi

www.ombudsman.or.id/ttgkami-visi

www.ombudsman.or.id/ttgkami-struktur

www.ombudsman.or.id/whatnew 7jun99. kompas

www.ombudsman.or.id/whatnew 31dectabel'

uww.ombudsman.or.id/detailinformasibaru 